\title{
PENINGKATAN KETERAMPILAN BERTANYA SISWA MELALUI FAKTOR PEMBENTUKNYA
}

\author{
Yeni Nur Prilanita, dan Sukirno \\ Fakultas Ekonomi Universitas Negeri Yogyakarta \\ email: prilanita@gmail.com,soekirno_uny@yahoo.co.id
}

\begin{abstract}
Abstrak: Penelitian ini bertujuan untuk mengetahui pengaruh penggunaan metode pembelajaran, penguatan guru, dan penerimaan teman sebaya terhadap pemahaman materi ekonomi dan keterampilan bertanyasiswa. Penelitian ini merupakan survei. Populasi dari penelitian adalah 647 siswa SMA di Sleman yang menggunakan K-13. Sampel sejumlah 472 siswa menggunakan teknik disproportional stratified random sampling. Data dikumpulkan lewat angket, pengamatan, dan wawancara. Analisis data menggunakan analisis regresi berganda dan analisis jalur. Hasil penelitian adalah sebagai berikut. Pertama, ketepatan metode pembelajaran dan penguatan guru memberikan pengaruh langsung yang signifikan terhadap pemahaman materi siswa, sedangkan penerimaan teman sebaya tidak. Kedua, penguatan guru, penerimaan teman sebaya, dan pemahaman materi memberikan pengaruh secara langsung dan signifikan terhadap keterampilan bertanya siswa, sedangkan metode pembelajaran tidak. Apabila dilihat dari pengaruh tidak langsung, metode pembelajaran dan penguatan dari guru memberikan pengaruh tidak langsung terhadap keterampilan bertanya. Penerimaan teman sebaya cenderung memberikan pengaruh langsung.
\end{abstract}

Kata Kunci: metode pembelajaran, penguatan guru, teman sebaya, pemahaman materi, keterampilan bertanya

\section{IMPROVING STUDENTS' QUESTIONING SKILLS THROUGH THEIR MOTIVATING FACTORS}

\begin{abstract}
The study investigates the effects of the teaching method, teacher's reinforcement and peer acceptance on students' comprehension on the learning materials of economicsand on students' questioning skills. A survey was conducted to 647 high school students in Sleman Regency which applied K-13. A sample of 472 students wererecruited using the disproportional stratified random sampling. Statistical technique of multiple regression and path analysis were deployed to analyze the data. The results revealed that, firstly,while the teaching method and teacher's reinforcementhad significant effect on students' comprehension on economics learning material, peer acceptance did not have any. Secondly, teacher's reinforcement, peer acceptance and comprehension of the materials gave a direct effecttowardsstudents' questioning skills. However, the teaching methods did not have a direct effect. They, yet, simultaneously had direct and significant effect on students' questioning skills. Teacher's reinforcement and appropriateness of the teaching method had indirect effect on students' questioning skills. Peer acceptence tended to have a direct effect.
\end{abstract}

Keywords: teaching method, teacher's reinforcement, peer group, comprehension of the subject matter, questioning skills

\section{PENDAHULUAN}

Bertanya menjadi suatu komponen penting dalam komunikasi sehari-hari. Banyak makna yangtersirat dalam pertanyaan yang terlontar. Pertanyaan yang terlontar dapat menggambarkan sejauh mana pengetahuan individu terhadap suatu kasus bahkan bisa melihat darimana asal penanya. Bahkan, bisa jadi pertanyaan tersebut menjadi suatu awal terbentuknya teori baru.
Pada saat mencapai tahap memahami suatu teori, seseorang akan membuat kritisan dengan membandingkan teori yang dipelajari dan kehidupan yang dia alami. Disadari atau tidak, kritisan tersebut pun muncul dimulai dari suatu pertanyaan. Tentu saja semakin banyak pengalaman seseorang dalam belajar atau memiliki pengetahuan yang lebih maka akan lebih kompleks pula pertanyaan yang akan disampaikan. Seseorang yang 
memiliki pengalaman belajar lebih banyak akan memberikan pertanyaan yang lebih kompleks. Pengalaman belajar tersebut tercermin dengan tingkat pengetahuan atau pemahaman seseorang terhadap suatu materi. Jadi semakin tinggi tahapan pemahaman seseorang semakin kompleks pula pertanyaan yang akan muncul.

Boswell (2015:1-2), pertanyaan kognitif yang lebih rendah mencerminkan pertanyaan pada tingkat pengetahuan dan pemahaman atau lebih secara faktual. Sementara pertanyaan kognitif yang lebih tinggi berusaha untuk menuntut jawaban pada tingkat aplikasi, analisis, sintesis dan evaluasi. Pernyataan tersebut pun selaras dengan hasil penelitian Clasen (Savage (1998:291) yang menyatakan bahwa "The level of student thinking, in fact, is directly proportional to the level of questions asked".

Dalam proses pembelajaran, sering kali dijumpai siswa kesulitan untuk melontarkan suatu pertanyaan yang berkaitan dengan materi ajar. Menurut pengakuan sebagian besar dari siswa, mereka merasa kebingungan dalam melontarkan pertanyaan. Hal tersebut karena mereka tidak menguasai materi ajar yang telah disampaikan. Pernyataan tersebut didukung oleh pernyataan Mucher (2007:267) dalam jurnalnya pertanyaan adalah kemampuan yang dapat diperoleh dan ditingkatkan melalui pendidikan, bukan kualitas bawaan.

Daerah Istimewa Yogyakarta yang merupakan kota pelajar pun memiliki keterampilan bertanya yang cenderung rendah. Berdasarkan hasil pengamatan di beberapa sekolah baik negeri maupun swasta, sebanyak 108 siswa yang menjadi objek pengamatan hanya terdapat 7 siswa atau sebesar $6,48 \%$ siswa yang melontarkan pertanyaan. Kecenderungan siswa bertanya pun hanya sebatas menerjemahkan suatu materi. Tidak jauh berbeda kondisi siswa SMA di Kabupaten Sleman. Selama proses pembelajaran, siswa cenderung enggan bertanya. Mereka melontarkan pertanyaan pada saat ingin mengonfirmasi yang belum jelas yang mereka dengar sehingga guru pun hanya mengulangi apa yang sebelumnya telah disampaikan.

Berdasarkan klasifikasi taksonomi bertanya yang disampaikan oleh Parera (1986:13-17), kecenderungan siswa di atas berada di antara tingkatan II, yaitu antara mengingat dan menghafal dan menerjemahkan. Hasil temuan ini pun didukung oleh hasil temuan Catherine Cornbleth pula yang menyatakan "... that students in junior and senior high school social studies classes asked more memory (knowledge recall) questions than all other question types combined" (Cornbleth, 1975:219).

Apabila melihat hasil ujian nasional tahun 2015, Daerah Istimewa Yogyakarta khususnya kabupaten Sleman dalam mata pelajaran ekonomi memiliki kategori D (Pusat Penilaian Pendidikan, 2015). Pemahaman materi yang cenderung rendah mengakibatkan siswa kekuranganinput untuk mengembangkan materi yang dimilikinya sehingga produksi pertanyaan kurang maksimal.

Savage (1998:291)mengemukakan bahwa $70-80 \%$ siswa mengajukan pertanyaan sebatas factual recall. Siswa pun cenderung hanya "read it and repeat it" sehingga siswa cenderung hanya mengingat tanpa ada proses berpikir yang lebih tinggi. Hal tersebut yang mendasari $80-90 \%$ siswa cepat melupakan materi yang diajarkan. Lebih lanjut, penelitian yang dilakukannya pun menyatakan bahwa pertanyaan dengan tingkatkan yang tinggi pun memperlihatkan tingkatan kognitif yang tinggi pula.

Berbagai hal yang menyebabkan rendahnya keterampilan siswa dalam bertanya. Catherine Cornbleth menyebut-kan setidaknya terdapat 3 hal yang menyebabkan hal tersebut, yaitu: perilaku dan kebiasaan guru di dalam kelas, umur siswa dan status sosial ekonomi siswa tersebut (Cornbleth, 1975:219-220). Perilaku dan kebiasaan guru melingkupi ketersediaan kesempatan siswa untuk berperan di dalam kelas. Umur siswa menunjukkan kesiapan siswa dalam berpikir. Sedangkan status sosial ekonomi siswa berkaitan dengan penerimaan siswa dengan siswa lain.

Berdasarkan catatan pendidik.web.id yang diunggah oleh Lubis (2011) setidaknya ada tiga alasan mengapa siswa enggan untuk bertanya, yaitu: ketidakpercaya diri siswa, siswa kurang memahami materi dan guru yang kurang komunikatif. Apabila terdapat ketiga alasan tersebut masih rendah maka tidak dapat dipungkiri keterampilan bertanya siswa pun cenderung rendah.

Kecenderungan metode pembelajaran yang digunakan di Kabupaten Sleman adalah metode pembelajaran ceramah. Menurut mereka, metode pembelajaran ceramah paling cocok diterapkan dalam pembelajaran sebab beban materi belajar yang terlalu banyak. Namun apabila melihat kadar cara belajar siswa aktif (CBSA), metode pembelajaran ceramah memiliki kadar CBSA 
paling rendah (Djamarah, 2005:227). Penguatan dari guru yang umum diberikan kepada siswa selama proses belajar pun hanya sebatas senyuman dan acungan jempol. Walaupun sebenarnya guru memberi nilai lebih apabila siswa aktif dalam pembelajaran, namun siswa cenderung tidak mengetahui. Selain itu, pola pergaulan siswa khususnya di kabupaten Sleman, pada saat bermain enggan membahas materi pembelajaran. Mereka cenderung membahas hal-hal yang berkaitan dengan masalah pribadi dan kegiatan lainnya yang sedang mereka gemari.

Dalam penelitian ini bertujuan untuk melihat pengaruh dari faktor-faktor pembentuk tersebut terhadap peningkatan keterampilan bertanya siswa SMA di Kabupaten Sleman.

\section{METODE}

Jenis penelitian yang telah dilakukan adalah penelitian eksplanatif asosiatif dengan pendekatan kuantitatif prediksi. Penelitian ini dilakukan di SMA yang menggunakan Kurikulum 2013 (K-13) di Kabupaten Sleman selama semester genap tahun ajaran 2015/2016.

Populasi dalam penelitian adalah siswa kelas XI baik dari program IIS maupun MIA yang mengikuti kelas ekonomi. Populasi berjumlah 647 siswa dengan 484 siswa dari program IIS dan 163 dari program MIA. Dengan jumlah yang berbeda jauh tersebut maka digunakan disproportional stratified random sampling untuk menentukan sampel yang digunakan. Seluruh siswa dari program MIA diambil sebagai sampel dan siswa dari program IIS dilakukan perhitungan sampel. Untuk sampel path analysis sampel ideal berjumlah 400-1000 (Sarwono, 2012:29). Dengan seperti itu sampel untuk program IIS berjumlah 237 responden.

Dalam mengumpulkan data dilakukan observasi awal, wawancara kepada pihak-pihak terkait dan memberikan angket mengenai ketepatan metode pembelajaran, penguatan dari guru, penerimaan teman sebaya dan keterampilan bertanya kepada siswa. Angket mengenai ketepatan metode pembelajaran, penguatan dari guru dan penerimaan teman sebaya berupa pernyataan untuk mengukur persepsi responden tentang masing-masing variabel yang dinyatakan dalam skala likert. Angket keterampilan bertanya berupa tabel penyekoran sesuai taksonomi revisi. Semakin banyak pertanyaan yang terlontar dan atau semakin tinggi pertanyaan tersebut teriden- tifikasi dalam kategori taksonomi revisi serta pertanyaan-pertanyaan tersebut sesuai dengan materi yang telah ditentukan maka semakin tinggi pula keterampilan bertanya siswa tersebut. Untuk mengukur pemahaman siswa digunakan nilai hasil tes kendali mutu yang didapat dari masing-masing sekolah. Sebelum penelitian dilakukan,uji instrumen kepada 120 siswa dalam populasi.

Data hasil uji coba kemudian diolah untuk menguji validitas dan reliabilitas instrumen. Setelah semua instrumen dinyatakan valid dan reliabel, penelitian dapat dilakukan. Untuk data keterampilan bertanya, sebelum diolah, dilakukan analisis pengkategorian pertanyaan. Untuk mendapatkan data yang tepat untuk dilakukan analisis, dilakukan analisis data outlier. Adapun uji prasyarat yang dilakukan sebelum melakukan analisis regresi berganda adalah uji normalitas, uji linearitas, uji multikolinearitas, dan uji heteroskedastisitas. Data-data tersebut kemudian dianalisis menggunakan teknik analisis regresi berganda dan analisis jalur.

Analisis regresi berganda digunakan untuk melihat pengaruh secara langsung, sedangkan analisis jalur digunakan untuk melihat pengaruh secara tidak langsung dari masing-masing variabel independen terhadap variabel dependennya. Terdapat dua struktur persamaan dalam penelitian ini, yaitu:

$Y_{1}=P Y_{1} X_{1}+P Y_{1} X_{2}+P Y_{1} X_{3}+e_{1}$ (sebagai persamaan substruktur 1 )

$Y_{2}=P Y_{2} X_{1}+P Y_{2} X_{2}+P Y_{2} X_{3}+e_{2}$ (sebagai persamaan substruktur 2)

\section{HASIL DAN PEMBAHASAN}

Analisis dilakukan kepada 479 responden. Namun setelah dilakukan analisis data outlier, 7 data responden harus dikeluarkan sehingga data yang dianalisis berjumlah 472 .

Hasil dari masing-masing uji prasyarat menyatakan bahwa data berdistribusi normal dan linier, serta terbebas dari multikolinearitas dan heteroskedastisitas. Dengan melihat hasil uji prasyarat tersebut diketahui data sudah memenuhi syarat untuk dilakukan analisis deskriptif, analisis regresi berganda dan analisis jalur.

Dalam analisis deskriptif didapat 7,6 \% siswa mengikuti bimbingan belajar ekonomi di luar jam belajar di sekolah dan 3,6\% siswa tinggal tidak dengan orangtua. Dengan seperti itu, mayoritas siswa memiliki kondisi yang sama. Selain itu $81,1 \%$ siswa memiliki keterampilan bertanya 
sangat rendah; $46,6 \%$ siswa memiliki pemahaman materi ekonomi yang tinggi; $50,2 \%$ siswa merasa ketepatan metode pembelajaran yang diterapkan tinggi; $39,8 \%$ siswa merasa penguatan yang diberikan guru sedang; dan 69,1\% siswa merasa tingkat penerimaan teman sebaya tinggi.

Menurut Hanifah dan Cucu ada beberapa faktor yang mempengaruhi belajar, antara lain adalah pengajar yang professional dan atmosfir pembelajaran yang partisipatif dan interaktif (Hanafiah dan Suhana, 2012:8-9). Kedua faktor tersebut dapat dibentuk oleh ketepatan metode pembelajaran, penguatan dari guru dan penerimaan teman sebaya.

Clasen (Savage, 1998:291)menyatakan bahwa "The level of student thinking, in fact, is directly proportional to the level of questions asked" Seperti yang diungkapkan di awal, bahwa rendahnya keterampilan bertanya dipengaruhi setidaknya terdapat tiga hal, yaitu perilaku dan kebiasaan guru di dalam kelas yang dapat dilihat dari pemilihan metode pembelajaran yang digunakan serta pemberian pengutan, umur siswa dan status sosial ekonomi siswa tersebut menggambarkan penerimaan siswa dalam lingkungan (Cornbleth, 1975:219-220). Melihat faktor-faktor yang memengaruhi dari masing-masing variabel memilikikemiripan. Dengan seperti itu, terdapat indikasi bahwa variabel-variabel independen tersebut memberi pengaruh baik secara langsung maupun tidak langsung terhadap variabel dependen. Untuk melihat pengaruh dari variabel-variabel dapat dilihat dari tabel dan paradigmaregresi berganda yang ditunjukkan pada Tabel 1 dan Gambar 1.

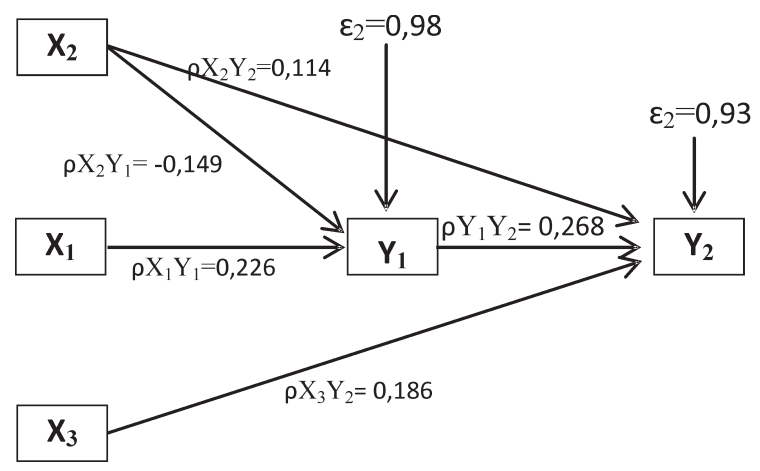

\section{Gambar 1 Paradigma Analisis Struktur I} dan II

Hasil analisis regresi berganda dan analisis jalur yang tampak dalam tabel dan paradigmamenunjukkan 12 temuan baik pengaruh secara langsung dan tidak langsung. Temuan pertama, secara partial ketepatan metode pembelajaran mempu-nyai pengaruh yang signifikan terhadap pemahaman materi ekonomi yang dimiliki siswa (nilai sig. $0,000<0,05$ ). Apabila metode pembelajaran tersebut tidak dapat menarik siswa dengan pembelajaran di kelas terlalu cepat, sulit dipahami, kurang adanya interaksi siswa dan guru dan lain sebagainya maka pemahaman siswa terhadap suatu materi yang menjadi tujuan tersebut sulit untuk tercapai. Hal tersebutmenunjukkan bahwa salah satu faktor yang sering dianggap menurunkan motivasi siswa remaja untuk belajar adalah guru dalam menyampaikan materi (Sarwono,. 2007:125).

Lumpkin, dkk (Lumpkin, 2015:352) pun menyatakan hal serupa. Hasil penelitian mengenai persepsi mahasiswa sarjana dan pascasarjana,

Tabel 1. Hasil Analisis Regresi Berganda

\begin{tabular}{ccccccc}
\hline \multicolumn{2}{c}{ Variabel } & $\mathrm{B}$ & $\mathrm{R}^{2}$ & Adjusted $\mathrm{R}^{2}$ & \multicolumn{2}{c}{ Sig. } \\
\hline $\mathrm{X}_{1}$ & & 0,165 & & & 0,000 & \\
$\mathrm{X}_{2}$ & $\mathrm{Y}_{1}$ & $-0,106$ & 0,028 & 0,022 & 0,000 & 0,004 \\
$\mathrm{X}_{3}$ & & 0,005 & & & 0,910 & \\
& & & & & & \\
$\mathrm{Y}_{1}$ & & 0,278 & & & 0,000 & \\
$\mathrm{X}_{1}$ & & 0,057 & & & 0,236 & \\
$\mathrm{X}_{2}$ & $\mathrm{Y}_{2}$ & 0,085 & 0,138 & 0,131 & 0,010 & 0,000 \\
$\mathrm{X}_{3}$ & & 0,169 & & & 0,000 & \\
& & & & & & \\
\hline
\end{tabular}

Keterangan:

X1 : Ketepatan Metode Pembelajaran

$\mathrm{X} 2$ : Penguatan dari Guru

X3 : Penerimaan Teman Sebaya

Y1 : Pemahaman Materi Ekonomi

Y2 : Keterampilan Bertanya Siswa 
menyatakan bahwa kegiatan di dalam kelas menentukan outcomes dari pembelajaran tersebut. Kamboj dan Singh (2015:289) mengungkapkan bahwadengan metode pembelajaran yang tepat akan memberikan kenyamanan dan ketegangan selama proses pembelajaran tersebutdan akhirnya memberikan peserta didik beberapa cara untuk unggul.

Temuan kedua, secara parsial penguatan dari guru memiliki pengaruh yang signifikan terhadap pemahaman materi ekonomi siswa (nilai sig. $0,000<0,05$ ). Namun, apabila melihat nilai Beta sebesar 0,106 dan bernilai negatif, hal tersebut menggambarkan bahwa sifat pengaruh variabel tersebut adalah negatif sehingga apabila penguatan dari guru ditingkatkan maka semakin menurun pemahaman materi ekonomi siswa. Apabila melihat kedua data (penguatan dari guru dan pemahaman materi ekonomi siswa) tersebut disilangkan (crosstabs) maka terlihat kecenderungan siswa yang memiliki tingkat pemahaman tinggi dansangat tinggi hanya diberikan penguatan sedang sedangkan siswa yang memiliki tingkat pemahaman sedang ke tinggiyang mendapat penguatan dari guru dengantingkatan tinggi. Dengan seperti itu siswa yang memiliki pemahaman materi lebih kecil cenderung diberikan penguatan dari guru lebih tinggi.

Selain itu, respon setiap manusia khususnya siswa terhadap suatu tindakan itu berbeda-beda. Baik dari kedalaman respon maupun persepsi respon. Setidaknya ada 2 hal yang membentuk respon tersebut yaitu (i) dalam sensitivitas mereka terhadap perubahan nilai hasil dan atau (ii) dalam sensitivitas mereka terhadap perubahan hubungan kausal antara tindakan dan hasil pengiriman (Dezfouli dan Balleine, 2012:1036). Walaupun tindakan yang diberikan sama terhadap seluruh siswa, belum tentu respon yang diberikan siswa akan sama. Hal tersebut disebabkan dari penerimaan tindakan oleh siswa pun juga berbeda. Itu pun yang mengakibatkan sering terdapat "kegagalan" penguatan untuk membuat suatu perilaku yang diinginkan. Semua itu didasari oleh kondisi manusia sangat kompleks (Shahan, 2010:1).

Tentu banyak cara guru dalam melakukan penguatan kepada siswanya. Salah satu cara yang dapat dilakukan oleh guru dalam memberikan penguatan adalah mengikutsertakan mereka dalam proses pembelajaran itu sendiri. Siswa yang kurang aktif dilatih untuk menjadi lebih aktif dengan beberapa treatment yang dilakukan oleh guru. Seperti yang diutarakan oleh Tubin (2015:640) bahwa "the purpose of the present study is to explore the process, routines, and structuration at successful schools leading their students to high achievements". Dengan adanya penguatan tersebut diharapkan permasa-lahan siswa dalam proses pembelajaran dapat tertanggulangi. Penguatan dari guru tentu bukan obat mujarab untuk merubah perilaku siswa agar lebih baik (Peed dan Pinsker, 1978:501). Tetapi, melalui penguatan yang berkelanjutan dapat meningkatkan keterlibatan akademik siswa-siswa tersebut (Trevino-Maack, dkk, 2015:347).

Pada temuan ketiga, penerimaan teman sebaya tidak memiliki pengaruh yang signifikan terhadap pemahaman materi ekonomi siswa (nilai sig. $0,910>0,05)$. Hasil penelitian tersebut selaras dengan hasil penelitian Kathryn dan Kathryn yang menyatakan "aspects of peer relationship are related to classroom achievement indirectly" (Wentzeldan Caldwell, 1997:1198). Mereka menyatakan bahwa penerimaan teman sebaya cenderung memengaruhi tingkah laku siswa terlebih dahulu. Dengan seperti itu penerimaan teman sebaya tidak langsung mempengaruhi pemahaman materi ekonomi siswa tetapi mempengaruhi tingkah laku siswa yang tidak menutup kemungkinan akan membawa siswa tersebut mencapai pemahaman materi yang diinginkan.

Kathryn dan Bowen (1997:413) juga menyatakan hal yang serupa. Mereka menyatakan bahwa pemerimaan teman sebaya lebih mempengaruhi secara tidak langsung daripada langsung terhadap prestasi belajar siswa. Kathryn dan Gary menambahkan "The behavior variable, avoidance of problem behavior, provides the strongest path of connection between peer group acceptance and academic performance".

Kecenderungan para remaja pada saat pergi, mereka enggan untuk membicarakan tugastugas atau materi yang berkaitan dengan kegiatan pembelajaran di dalam kelas. Remaja cenderung akan membahas kejadian apa yang sedang hangat terjadi, masalah pribadi, tren terbaru serta memberikan komentar pada tingkah laku teman yang lain yang bagi mereka layak untuk dibahas pada saat itu. Berdasarkan hal tersebut, wajar apabila penerimaan teman sebaya tidak berpengaruhi secara langsung terhadap pemahaman atas suatu materi tetapi cenderung akan membentuk tingkah laku siswa. 
Temuan keempat menyatakan bahwa pengaruh ketepatan metode pembelajaran, penguatan dari guru dan penerimaan teman sebaya secara simultan terhadap pemahaman materi ekonomi yang dimiliki oleh siswa (nilai sig. 0,004<0,05). Banyak hal yang mempengaruhi keberhasilan pembelajaran di dalam kelas baik dari faktor internal maupun eksternal siswa. Faktor-faktor tersebut tidak hanya memberikan pengaruh yang positif tetapi ada pula yang memberikan pengaruh negatif dalam ketercapaian keberhasilan pembelajaran. Hanifah dan Cucu ada beberapa faktor yang mempengaruhi belajar, antara lain adalah pengajar yang profesional dan atmosfir pembelajaran yang partisipatif dan interaktif (Hanafiah dan Suhana, 2012:8-9).

Pengajar yang professional dengan berbagai kompetensi yang dimilikinya akan membantu dalam penyampaian materi kepada siswa. Dengan penyampaian materi yang baik akan terlihat dalam penerimaan materi oleh siswa. Selain itu, apabila atmosfir dalam kelas tersebut kondusif dalam proses pembelajaran maka akan menimbulkan rasa nyaman bagi masyarakat di dalam kelas tersebut. Dengan seperti itu penerimaan materi yang akan terlihat dari pemahaman materi oleh siswa pun akan semakin baik.

Kedua faktor tersebut dapat terbentuk dengan penguatan dari guru, ketepatan metode pembelajaran dan penerimaan teman sebaya. Pengajar yang profesional pun memiliki keterampilan dalam memberikan penguatan kepada siswa serta memiliki keterampilan memilih metode pembelajaran yang sesuai. Dengan adanya penguatan dari guru dan ketepatan dalam pemilihan metode pembelajaran pun dapat membentuk atmosfir dalam pembelajaran yang semakin kondusif untuk proses pembelajaran. Ditambah lagi apabila dalam suatu kelas pembelajaran tersebut penerimaan teman sebaya tinggiakan membentuk kelas yang lebih nyaman sebab tidak terdapat kecanggungan antar teman sehingga mereka akan melakukan apapun yang mereka ingin lakukan khususnya dalam hal meningkatkan pemahaman materi.

Pada temuan kelima, tidak terdapat pengaruh langsung dan signifikan ketepatan metode pembelajaran terhadap keterampilan bertanya siswa (sig. 0,236>0,05). Metode pembelajaran membantu kegiatan pembelajaran dapat berlangsung secara sistematis, terarah, lancar, dan efektif. Metode pembelajaran cenderung hanya membentuk proses pembelajaran menjadi lebih kondusif.
Namun tidak ada jaminan untuk membentuk keterampilan siswa yang terakomodasi dalam proses pembelajaran. Ditambah lagi kenyataan bahwa peran guru masih sangat sentral dalam pembelajaran. Salah satu faktor yang menentukan motivasi belajar siswa adalah guru (Sarwono, 2007:125). Melihat kecenderungan faktor dominan tersebut tentu saja ketepatan metode pembelajaran dianggap baik adalah yang justru banyak terdapat keterlibatan guru dalam proses pembelajaran.

Menurut Alex Bourne yang dikutip oleh Utomo Dananjaya menyatakan bahwa guru yang dominan mungkin saja memasukkan sejuta fakta ke dalam otak anak, tetapi anak akan tetap menjadi tidak terdidik (Dananjaya, 2013:17). Tentu saja bukan hal yang salah apabila guru menjadi tokoh sentral dalam pembelajaran. Dengan seperti itu pun, tidak mengurangi proses pembelajaran berjalan dengan baik. Hanya saja keterampilan siswa cenderung kurang terasah khususnya dalam bertanya. Hal tersebut disebabkan siswa dijejali berbagai materi tanpa harus mereka mengeksplor apa yang mereka miliki.

Hal tersebut selaras dengan penelitian Oyediji dan Okwilagwe yaitu tidak ada pengaruh metode pembelajaran dengan meningkatkan berpikir kritis siswa. Walaupun metode pembelajaran tersebut mempengaruhi prestasi belajar siswa secara signifikan (Oyediji dan Okwilagwe, 2015:1). Keterampilan bertanya merupakan bentuk dari berpikir kritis siswa. Pada saat metode pembelajaran tidak memberikan pengaruh terhadap berpikir kritis siswa, maka metode pembelajaran tersebut pun tidak mempengaruhi keterampilan berpikir kritis siswa secara signifikan juga.

Apabila dikembalikan dengan fungsi metode pembelajaran yaitu membantu kegiatan pembelajaran dapat berlangsung secara sistematis, terarah, lancar dan efektif tentu saja keterampilan bertanya atau berpikir kritis tidak sepenuhnya dilahirkan dari itu. Berpikir kritis tidak hanya membutuhkan logika. Oyediji dan Okwilagwe pun menambah banyak hal yang dibutuhkan untuk membentuk berpikir kritis tersebut. Faktor-faktor tersebut antara lain harus memiliki intepretasi aktif, evaluasi, observasi, informasi, argumendan lain sebagainya. Hal-hal tersebut terbentuk oleh banyak hal di lingkungan siswa sendiri tidak hanya metode pembelajaran.

Temuan keenam, penguatan dari guru memiliki pengaruh langsung dan signifikan terhadap keterampilan bertanya siswa (sig. 0,010<0,05). 
Manusia belajar dari pengalaman mereka. Seperti halnya siswa belajar melalui pengalaman dengan meniru perilaku orang lain. Mereka mengulangi tindakan tersebut dengan harapan mereka akan memperoleh seperti yang pernah mereka peroleh sebelumnya. Dengan seperti itu, pada saat menghendaki siswa melakukan perilaku yang positif untuk dirinya, dapat melakukan suatu pengkondisian yang membahagiakan bagi mereka.

Guru sebagai makhluk dewasa dan salah satu pemegang kontrol dalam berjalannya suatu pembelajaran di kelas berhak melakukan suatu pengkondisian tersebut. Salah satu cara yang dilakukan guru untuk meningkatkan perilaku positif siswa dengan memberikan penguatan. Dengan adanya penguatan, siswa akan mengetahui tindakan mana yang baik dan benar untuk dilakukan kembali serta tindakan yang tidak pantas dilakukan kembali.

Bertanya merupakan tindakan yang baik dan mendukung tercapainya pemahaman siswa pada tingkatan yang lebih tinggi. Hal tersebut disebabkan siswa akan terlatih berpikir kritis. Apabila menghendaki tindakan ini kembali dilakukan, maka pada saat siswa bertanya dapat diberikan penguatan. Penguatan tersebut dapat dilakukan secara verbal seperti memuji pertanyaan yang dilontar-kan atau menjawab pertanyaan siswa dengan antusias. Atau dapat melalui nonverbal seperti memberikan acungan jempol, senyuman serta nilai tambahan pada siswa yang bertanya. Penguatan-penguatan yang dilakukan guru tersebut memberikan efek bahagia terhadap siswa, sehingga siswa pun akan terpacu untuk melakukan tindakan kembali.

Pada saat semakin tinggi intensitas bertanya siswa maka siswa pun akan terbiasa membuat pertanyaan. Siswa pun akan semakin kritis dengan suatu hal. Dengan seperti itu, semakin banyak penguatan yang dilakukan oleh guru maka akan semakin tinggi pula keterampilan bertanya yang dimiliki oleh siswa.

Temuan tersebut didukung oleh penelitian Guéguen, dkk bahwa ada pengaruh positif dari penguatan dalam bentuk verbal terhadap partisipasi siswa dalam pembelajaran (Guéguen, dkk, 2015:54). Todd (2016:2) dalam artikelnya pun menyatakan pentingnya pengakuan atas tindakan baik yang dilakukan siswa. Selain itu, dengan pujian pada saat siswa berkontribusi dalam kegiatan pembelajaran dan pantang menyerah dalam belajar akan menumbuhkan keunggulan dalam bidang akademik di kelas.
Temuan ketujuh menyatakan bahwa penerimaan teman sebaya memiliki pengaruh langsung dan signifikan terhadap keterampilan bertanya (sig. $0,000<0,05$ ). Siswa SMA adalah manusia yang berada dalam usia remaja. Usia dimana pengaruh teman sebaya lebih mendominasi daripada aspek lain diluar dirinya. Hal tersebut pun diungkapkan oleh Glen J. Veed bahwa “...research on peer networks has demonstrated that the influence and importance of peers appears to increase beginning in early adolescence. This trend continues until the influence of peers peaks in middle adolescence and begins a gradual decline into later adolescence" (Veed, 2009:16).

Setiap manusia membutuhkan aktualisasi diri terhadap lingkungannya. Merasa diterima pun menjadi indikator suksesnya aktualisasi diri tersebut. Bagi sebagian besar remaja, menjadi popular bersama kawan sebayanya merupakan motivator yang kuat (Santrock, 2011:446). Hartup menyatakan bahwa ada perbedaan pengaruh antara anak yang memiliki teman dan tidak memiliki teman. Anak yang memiliki teman cenderung lebih ramah, mudah bekerjasama, altruistik, percaya diri dan tidak kesepian (Hartup, 1992:2).

Kepemilikan teman sebaya dapat mempengaruhi tingkah laku, keterlibatan dalam kegiatan sekolah juga pencapaian prestasi akademiknya. Hal tersebut disebabkan anak yang memiliki banyak teman dan diterima dalam kelompoknya akan menunjukkan perubahan positif sesuai dengan karakteristik penerimaan kelompok sebayanya memiliki prestasi akademik yang baik pula (Sumiyati dan Chairunnisa, 2010:112). Lebih lanjut kelompok teman sebaya merupakan sumber afeksi, simpati, pemahaman, dan penuntun moral; tempat bagi sebuah eksperimen; dan pengaturan untuk mencapai otonomi serta kemandirian dari orangtua (Papalia dan Feldman, 2014:68).

Salah satu fungsi utama dari kelompok teman sebaya adalah untuk menyediakan berbagai informasi mengenai dunia di luar keluarga. Selain itu dengan kelompok teman sebaya, remaja menerima umpan balik mengenai kemampuan mereka (Santrock, 2003:219-220). Pada masa remaja telah memasuki tahap perkembangan kognitif operasional formal. Menurut Ali dan Asrori, tahap ini anak telah mampu mewujudkan suatu keseluruhan dalam pekerjaannya yang merupakan hasil dari berpikir logis (Ali dan Asrori, 2005:29). Remaja sudah mampu mengembangkan pikiran formalnya, mereka juga mulai mampu menca- 
pai logika dan rasio serta dapat menggunakan abstraksi.

Berdasarkan perkembangan intelektualnya, remaja tidak menerima mentah informasi yang diterimanya. Mereka dapat membuat suatu analisa dan menemukan suatu kesimpulan berdasarkan informasi-informasi yang diterima. Tentu saja semakin banyak informasi, semakin kompleks pula analisa yang dibuat oleh remaja tersebut. Apabila diibaratkan satu teman sebaya memberikan 1 informasi, maka semakin banyak teman semakin banyak pula informasi yang diterima. Salah satu indikator apakah seseorang tersebut diterima di lingkungannya atau tidak adalah jumlah teman yang dimiliki. Semakin banyak teman tentu saja seseorang akan merasa diterima. Dengan seperti itu semakin diterima oleh lingkungannya semakin kompleks pula analissis yang dapat dilakukan oleh remaja. Peningkatan intimasi dalam persahabatan di masa remaja mencerminkan perkem-bangan emosi dan kognitif(Papalia dan Feldman, 2014:69). Mereka pun menambahkan dengan keintiman yang lebih, remaja lebih bisa mengekspresikan pikiran dan perasaan mereka. Remaja pun dapat lebih siap mempertimbangkan sudut pandang orang, lebih mudah memahami pemikiran dan perasaan temantemannya.

Dengan penerimaan teman sebaya, remaja akan lebih bisa mengutarakan pendapatnya misalnya saja dengan bertanya. Melihat perkembangan intelek-tual remaja pada tahap abstraksi tentu saja mereka sudah dapat membayangkan dampak apa yang ditimbulkan oleh suatu teori. Remaja enggan untuk bertanya didasari oleh perasaan takut. "... we have questions we are sometimes afraid to ask" (Hall, dkk, 2014:390). Apabila remaja merasa diterima, perasaan-perasaan tersebut tentu akan menghilang. Dengan seperti itu, semakin diterima remaja pada kelompok teman sebaya semakin tinggi pula keterampilan bertanya siswa.

Pada temuan kedelapan, secara partial variabel pemahaman materi ekonomi memunyai nilai sig. $0,000(<0,05)$. Dengan seperti itu pemahaman materi ekonomi berpengaruh secara langsung dan signifikan terhadap keterampilan bertanya siswa. Pemahaman dapat diartikan sebagai kemampuan seseorang untuk mengartikan, menerjemahkan atau menyatakan suatu konsep atau teori dengan caranya sendiri baik itu dalam ranah kognitif dan afektif. Untuk mendapatkan pemahaman tersebut, seseorang dituntut untuk mencaritahu sendiri.
Entah melalui mendengarkan penjelasan orang lain, membaca atau bertanya untuk mencaritahu lebih lanjut.

Sebelum bertanya, tentu seseorang telah memiliki informasi awal yang menjadi dasar mereka bertanya. Dan akan dilanjutkan dengan pertanyaan-pertanyaan lain seiring informasi yang dilanjut dan kemampuan yang dimiliki oleh penanya. Dengan seperti itu, pemahaman seseorang terhadap suatu hal akan mempengaruhi keterampilan bertanya yang dimiliki penanya tersebut.

Temuan penelitian ini diperkuat dengan pendapat Clasen yang dikutip Luise B. Savage yang menyatakan bahwa "The level of student thinking, in fact, is directly proportional to the level of questions asked" (Savage, 1998:291). Carol Boswel pun berpendapat serupa. Dia menyatakan bahwa pertanyaan kognitif yang lebih rendah mencerminkan pada tingkat pengetahuan dan pemahaman $(\mathrm{C} 1$ dan $\mathrm{C} 2)$ sementara pertanyaan kognitif yang lebih tinggi mencerminkan pemahaman yang lebih tinggi pula yaitu menuntut jawaban pada tingkat aplikasi, analisis, sintesis dan evaluasi (Boswell, 2015:1-2).

Lebih lanjut, Ozgen dan Rustu menegaskan alasan pemahaman materi memberi pengaruh terhadap keterampilan bertanya. "Asking questioning is a natural outcome of being a human as a thinking creature" (Korkmaz dan Yesil, 2010:1006). Pendapat tersebut didukung oleh Catherine Cornbleth yang menyatakan bahwa pertanyaan siswa juga memperlihatkan informasi pemahamannya, proses memperoleh pemahaman serta perasaannya terhadap suatu hal (Cornbleth, 1975:220). Didahului dengan pemahaman tentang berpikir kritis akan memaksimalkan perkembangan berpikir kritis pula (Nusarastriya, 2013: 444). Dalam bertanya pun, siswa harus sesuai dengan konteks yang sedang dijadikan pembicaraan. Dengan seperti itu, sebelum bertanya tentu saja siswa tersebut telah memiliki bahan yang diramu menjadi pertanyaan.

"Living organisms are constantly being conditioned by their environment" hal tersebut yang diungkapkan oleh Skinner dalam An Introduction to Theories of Learning (Hergenhahn \& Matthew, 2015:81). Keterampilan bertanya pun tidak lepas dari teori tersebut. Perkembangan keterampilan yang dimiliki seseorang pun cenderung dipengaruhi oleh lingkungan sekitar mereka.

Keterampilan bertanya pun dikondisikan 
oleh lingkungan mereka. Paul dan Don melakukan pengamatan terhadap kelas DeVonne yang aktif dalam mengasah keterampilan menulis mereka. Hasil pengamatan tersebut menyatakan ada beberapa hal yang harus diperhatikan yaitu pentingnya iklim ruang kelas yang positif, teori pembelajaran kognitif (pengalaman atau pengetahuan siswa) dan motivasi siswa (Eggen dan Don, 2012:31-57)

Guru sebagai seorang arsitek dalam suatu kelas dapat mendisain kelas menjadi beriklim positif dan kondusif. Hal tersebut dapat ditempuh dengan ketepatan metode pembelajaran yang digunakan oleh guru yang bersangkutan. Sesuai dengan fungsinya, metode pembelajaran membuat proses pembelajaran dapat berlangsung secara sistematis, terarah, lancar dan efektif. Selain metode pembelajaran yang tepat, yang dapat menjadikan kelas beriklim positif adalah penerimaan siswa terhadap kehadiran teman sebayanya. Apabila seseorang merasa diterima, mereka akan cenderung lebih percaya diri. “... poor peer acceptance as a common underlying factor in emotional and behavioural problem development, particularly for children who are at risk for developing problems" (Menting, dkk, 2015:530).

Teori pembelajaran kognitif yang didalamnya mempelajari sejauh mana pengalaman belajar siswa. Pengalaman belajar siswa dapat dilihat dari kedalaman pemahaman siswa terhadap suatu materi.Pengalaman belajar tersebut digunakan sebagai sumber informasi awal untuk bertanya. Tanpa adanya pengalaman belajar tersebut, siswa akan merasa kebingungan dengan "mau bertanya apa". Seperti yang diungkapkan Sylvian Barnet dan Hugo Bedau, pada saat mau membuat kritisan paling tidak harus memiliki satu ide yang akan ditulis (Barnet dan Bedau, 1996:156-159). Dari informasi awal tersebut siswa dapat mengeksplornya dengan bertanya.

Memotivasi siswa dapat dilakukan guru melalui penguatan-penguatan pada saat siswa melakukan kegiataan pembelajaran. Hal tersebut berkaitan dengan kebutuhan dasar manusia yang salah satunya adalah aktualisasi diri dimana seseorang membutuhkan pengakuan dalam lingkungan. Dengan penguatan yang diberikan diri, siswa merasa diakui keberadaannya walaupun hanya dengan senyuman atau acungan jempol. Makhluk hidup khususnya siswa pun tidak terlepas untuk selalu memenuhi kebutuhan dasar tersebut. Dengan seperti itu mereka akan termotivasi.

Dengan terlaksananya ketiga unsur proses pembelajaran seperti yang dalam kelas DeVonne tersebut maka akan semakin tinggi pula keterampilan bertanya siswa. Hal tersebut didukung uji hipotesis yang menunjukkan bahwa nilai sig. sebesar 0,000 $(<0,05)$. Dengan seperti itu temuan kesembilan menyatakan bahwa faktor-faktor tersebut berpengauh secara simultan dan signifikan terhadap keterampilan bertanya siswa.

Pendapat ini pun diperkuat dengan pendapat dari Diane dan Ruth yang menyatakan bahwa keberhasilan atau pencapaian hasil di sekolah didasari oleh motivasi siswa dan kekuatan siswa (pemahaman materi) (Papalia, Diane E \& Ruth Duskin Feldman, 2014:33). Selain itu teman sebaya merupakan sumber informasi bagi perkembangan manusia baik dari segi afektif maupun kognitif(Papalia dan Feldman, 2014:33; Santrock, 2007:219-220). Semakin tinggi unsur-unsur tersebut memberikan kontribusi positif maka semakin tinggi pula keterampilan bertanya siswa.

Temuan kesepuluh menyatakan bahwa terdapat hubungan tidak langsung ketepatan metode pembelajaran terhadap keterampilan bertanya melalui pemahaman materi. Metode adalah cara yang di dalam fungsinya merupakan alat untuk mencapai suatu tujuan melalui fungsinya dalam proses pembelajaran. Metode pembelajaran berfungsi untuk membantu proses pembelajaran berjalan secara sistematis, terarah, lancar dan efektif. Semakin baik metode itu, semakin efektif pula pencapaian tujuan yang telah dirumuskan. Pada umumnya, tujuan pembelajaran di dalam kelas adalah meningkatnya pemahaman siswa yang dibuktikan dengan nilai yang di atas nilai ketuntasan minimal.

Dalam kelas terdapat berbagai faktor, yaitu: peserta didik, tujuan yang akan dicapai, situasi pembelajaran, fasilitas pembelajaran dan guru (Djamarah \& Aswan, 2010:21). Perumusan metode pembelajaran pun mempertimbangkan fakor-faktor tersebut sehingga hal-hal yang dapat diprediksi sebelumnya serta dibuat "penawar". Dengan seperti itu pemahaman materi pun akan semakin baik.

Hal tersebut didukung oleh temuan sebelumnya yang menyatakan bahwa ketepatan metode pembelajaran memberikan pengaruh yang positif terhadap pemahaman materi ekonomi siswa. Apabila siswa telah memiliki pemahaman 
materi, siswa memiliki modal atau peluang untuk bertanya dan mengkritisi yang berkaitan dengan pemahamannya tersebut. "As students are encouraged to think critically, they are directed toward processing the information and facts to form ideas." (Taylor dan Alber, 2002:69). Dengan seperti itu semakin baik pemahaman materi ekonomi, semakin baik pula keterampilan bertanya yang dimiliki siswa. Selaras dengan temuan sebelumnya yang menyatakan bahwa terdapat pengaruh yang positif pemahaman materi siswa terhadap keterampilan bertanya siswa.

Temuan kesebelas menyatakan terdapat pengaruh tidak langsung penguatan dari guru terhadap keterampilan bertanya siswa melalui pemahaman materi. Disadari atau tidak penguatan cenderung diberikan oleh guru kepada siswa yang mengalami permasalahan pembelajaran, misalnya saja pada siswa yang memiliki nilai kurang dari KKM atau menengah ke bawah. Walaupun pada prakteknya, penguatan tersebut diberikan kepada seluruh siswa dalam suatu kelas, namun akan lebih intensif diberikan kepada siswa cenderung memiliki permasalahan tersebut. Hal itu didasari tugas pokok penguatan adalah membuat siswa mau melakukan kembali tindakan positif. Penguatan adalah setiap konsekuensi yang memperkuat (maksudnya, meningkatkan frekuensi) perilaku (Slavin, 2008:184). Oleh sebab itu mengakibatkan penguatan dari guru berpengaruh negatif terhadap pemahaman materi ekonomi.

Dari pengaruh penguatan yang negatif tersebut membuat berpengaruh negatif pula terhadap keterampilan bertanya siswa. Hal tersebut didasari, bahwa dalam bertanya, siswa membutuhkan informasi awal sebagai modal siswa tersebut bertanya. Semakin banyak siswa memiliki informasi maka semakin banyak pula pertanyaan yang dapat diproduksi oleh siswa tersebut. Dengan seperti itu, keterampilan bertanya siswa pun akan meningkat seiring peningkatan informasi yang diterima siswa.

Selaian itu, pada temuan keduabelas menyatakan bahwa penerimaan teman sebaya tidak memunyai pengaruh tidak langsung terhadap keterampilan bertanya. Seperti yang diungkapkan pada pembahasan sebelumnya, bahwa penerimaan teman sebaya tidak berpengaruh signifikan terhadap pemahaman materi siswa. Hal tersebut disebabkan penerimaan teman sebaya cenderung memberikan pengaruh langsung terhadap tingkah laku siswa secara umum. Penerimaan teman sebaya cenderung memberikan pengaruh secara tidak langsung terhadap pemahaman teman sebaya.

Pemahaman materi ekonomi siswa dijadikan modal atau informasi awal untuk bertanya. Sama halnya dengan teman sebaya. Melalui teman sebaya siswa mendapatkan pengalaman dan informasi baru yang biasa lebih kontekstual daripada sumber informasi lainnya yang dapat dijadikan modal atau informasi awal dalam bertanya. Teman sebaya merupakan sumber informasi bagi perkembangan manusia baik dari segi afektif maupun kognitif(Papalia dan Feldman, 2014:33; Santrock, 2007:219-220). Dengan seperti itu, penerimaan teman sebaya pun cenderung dapat berpengaruh langsung terhadap keterampilan bertanya siswa.

Hal tersebut didukung oleh Bern yang menyatakan bahwa "Experience with peers enable children to acquire a wide range of skills, attitude, and roles that influence their adaptation throughout life" (Berns, 2013:250). Dengan teman sebaya, siswa akan mendapatkan keterampilan salah satunya keterampilan bertanya. Keterampilan bertanya semakin meningkat karena ada unsur dalam penerimaan teman sebaya yaitu kemampuan beradaptasi siswa juga bertambah. Dengan kemampuan beradaptasi tersebut, siswa akan merasa nyaman di dalam kelas. Siswa pun akan berkurang rasa segan melakukan aktifitas di dalam kelas khususnya dalam bertanya. Dengan demikian, penerimaan teman sebaya cenderung mempengaruhi keterampilan bertanya secara langsung.

\section{SIMPULAN}

Berdasarkan pengolahan deskripsi, analisis, interpretasi data dan pengolahan data statistik, maka dapat disimpulkan bahwa ketepatan metode pembelajaran (sig. $=0,001<0,05)$ dan penguatan dari guru (sig. $=0,016<0,05$ ) memberikan pengaruh langsung dan signifikan secara parsial terhadap pemahaman materi siswa. Sedangkan penerimaan teman sebaya tidak memberikan pengaruh langsung dan signifikan terhadap pemahaman materi siswa (sig. $=0,910>0,05)$. Namun ketepatan metode pembelajaran, penguatan dari guru dan penerimaan teman sebaya secara simultan memberikan pengaruh langsung dan signifikan terhadap pemahaman materi siswa (sig. $=0,004<$ $0,05)$. Selain itu, penguatan dari guru (sig. $=0,010$ $<0,05$ ), penerimaan teman sebaya (sig. $=0,000$ $<0,05)$ dan pemahaman materi (sig. $=0,000<$ $0,05)$ secara parsial memberikan pengaruh secara 
langsung dan signifikan terhadap keterampilan bertanya siswa. Sedangkan metode pembelajaran tidak memiliki pengaruh langsung dan signifikan terhadap keterampilan bertanya (sig. $=0,236>$ $0,05)$. Namun secara simultan, ketepatan metode pembelajaran, penguatan dari guru, penerimaan teman sebaya dan pemahaman materi memberikan pengaruh langsung dan signifikan terhadap keterampilan bertanya (sig. $=0,000<0,05$ ).

Apabila dilihat dari pengaruh tidak langsung, metode pembelajaran dan penguatan dari guru memberikan pengaruh tidak langsung terhadap keterampilan bertanya. Penerimaan teman sebaya cenderung memberikan pengaruh langsung daripada tidak langsung.

Keterampilan bertanya bukan suatu bawaan namun dapat dibentuk dan dikembangkan. Dengan melihat kaitan faktor pembentuknya, maka untuk memak-simalkan keterampilan bertanya tersebut disarankan untuk lebih memperhatikan dan mengembangkan faktor pembentuk tersebut.

\section{UCAPAN TERIMA KASIH}

Penulis mengucapkan terima kasih sebanyak-baynaknya kepada pihak yang telah membantu dan memfasilitasi penelitian ini, terutama para guru dan siswa di SMA N 1 Godean, SMA N 1 Kalasan, SMAN 1 Pakem, SMA N 1 Sleman, SMA N 2 Ngaglik, SMAN 1 Seyegan dan SMA N 1 Prambanan atas diperkenankannya melakukan penelitian. Atas kebaikannya tersebut, semoga dilipatgandakan balasan oleh Tuhan Yang Maha Esa.

\section{DAFTAR PUSTAKA}

Ali, Mohammad \& Mohammad Asrori. 2005. Psikologi Remaja: Perkembangan Peserta Didik. Jakarta: PT Bumi Aksara.

Barnet, Sylvian \& Hugo Bedau. 1996. Current Issues and Enduring Questions: A Guide to Critical Thinking and Argument, with Readings. Boston: St. Martin's Press.

Berns, R.M. 2013. Child, Family, School, Community: Socialization and Support. 9th Edition. Belmot: Thomson Learning, Inc.

Boswell, Carol. 2006. "The Art of Questioning: Improving Critical Thinking", dalam
Annual Review of Nursing Education, 4, hlm.291-296.

Cornbleth, Catherine. 1975. Student Questioning as a Learning Strategy. Association for Supervision and Curriculum Development.

Dananjaya, Utomo. 2013. Media Pembelajaran Aktif. Bandung: Penerbit Nuansa Cendekia.

Dezfouli, Amir \& Bernard W. Balleine.2012. "Habits, Action Sequences and Reinforcement Learning", dalamEuropean Journal of Neuroscience, 35, hlm.1036-1051.

Djamarah, Syaiful Bahri. 2005. Guru dan Anak Didik dalam Interaktif Edukatif: Suatu Pendekatan Teoretis Psikologis. Jakarta: Rineka Cipta.

Djamarah \& Aswan. 2010. Strategi Belajar Mengajar. Jakarta: Rineka Cipta.

Eggen, Paul \& Don Kauchak. 2012. Strategies and Models for Teachers: Teaching Content and Thinking Skills. Sixth Edition. Boston: Pearson Eduction, Inc.

Guéguen, Nicolas, et al. 2015. "I am sure you'll succeed": When a Teacher's Verbal Encouragement of Succeess Increase Children's Academic Performance", dalamLearning \& Motivation Journal, 52, hlm.54-59.

Hall, E. et al. 2014. Introduction to Teaching: Making a Difference in Student Learning. Canada: Sage Publications, Inc.

Hartup, Willard W. 1992. "Having Friends, Making Friends, and Keeping Friends: Relationships as Education Contexts", dalam ERIC Digenst, 19, hlm.1-5.

Hanafiah \& Cucu Suhana. 2012. Konsep Strategi Pembelajaran. Bandung: PT. Refika Aditama.

Hergenhahn,\& Matthew H.O. 2015. An Introduction to Theories of Learning.Ninth Edition. Boston: Pearson Eduction, Inc. 
Kamboj, Pooja \& Sushil Singh. 2015. "Effectiveness of Selected Teaching Strategies in Relation to the Learning Styles of Secondary School Students in India", dalamInterchange, 46, hlm.289-312.

Korkmaz, Ozgen, \& Rustu Yesil. 2010. “A Comparison of Different Teaching Apllications Based on Questioning in Terms of Their Effect Upon Pre-Service Teacher's Good Ques-tioning Skill", dalamProQuest Educational Journal, 44, hlm.1006-1020.

Papalia, Diane E. \& Ruth Duskin Feldman. 2014. Menyelami Perkembangan Manusia. Jakarta: Salemba Humanika.

Parera, Jos Daniel. 1986. Keterampilan Bertanya dan Menjelaskan. Jakarta: Penerbit Erlangga.

Peed, Steve \& Mark A. Pinsker. 1978. "Behavior Change Procedures in Junior and Senior High School", dalam Education \& Urban Society, 10, hlm.501-520.

Pusat Penilaian Pendidikan. 2015. Panduan Pemanfaatan Hasil UN Tahun Pelajaran 2014/2015 untuk Perbaikan Mutu Pendidikan.

Lubis, Muzzani. 2011. Mengapa Siswa Tidak Mau Bertanya?.http://www.catatanpendidik. web.id/ 2011/10/mengapa-siswa-tidakmau-bertanya.html diunduh31 Oktober 2015.

Lumpkin, Angela, et al. 2015. "Focusing Teaching on Students: Examining Student Perceptions of Learning Strategies", dalam Quest, 67 hlm.352-366.

Menting, Barbabara, el al. 2015. "Peer Acceptance and The Development of Emotional and Behavioural Problems", dalam International Journal of Behavioral Development, 39, hlm.530-540.

Mucher, Stephen. 2007. Building a Culture of Evidence Through Profesional Development. Eastern Michigan University, Ypsilanti, Michigan.
Nusarastriya, Yosaphat Haris, H. Sapriya, et al. 2013. "Pengembangan Berpikir Kritis dalam Pembelajaran Pendidikan Kewarganegaraan Menggunakan Project Citizen" dalamJurnal Cakrawala Pendidikan, 3, hlm.444-449.

Oyediji, Olubukola \& Eugena Okwilagwe. 2015."Investigating The Effects of SelfDirected Learning and Collaborative Methods on Junior Secondary School Students Social Studies Learniing Outcomes in Oyo State, Nigeria", dalam Problems of Education in The $21^{\text {st }}$ Century, 64, hlm.38-52.

Santrock, J.W. 2007. Remaja. Jakarta: Erlangga.

Santrock, J.W. 2003. Adolescence Psikologi Remaja. Jakarta: Erlangga.

Santrock, J.W. 2011. Life-span Development, $13^{\text {th }}$ Edition. New York: Mc Gray Hill.

Sarwono, Jonathan. 2012. Path Analysis dengan SPSS: Teori, Aplikasi, Prosedur Analisis untuk Riset Skripsi, Tesis dan Disertasi. Jakarta: PT Elex Media Komputindo.

Sarwono, Sarlito Wirawan. 2007. Psikologi Remaja. Jakarta: PT Raja Grafindo Persada.

Savage, Luise B. 1998. "Eliciting Critical Thinking Skills through Ques-tioning", dalam ProQuest, 71, hlm.291-293.

Shahan, Timothy A. 2010. "Conditioned Reinforcement and Response Strength", dalamJournal of The Experimental Analysis of Behavior, 93, hlm.269-289.

Slavin, Robert E. 2008. Psikologi Pendidikan: Teori dan Praktik, Jilid 1, Ed. Kedelapan (Terjemahan Marianto Samosir). Jakarta: PT Indeks.

Sumiyati, Ati \& Chairunnisa. 2010. "Hubungan Antara Penerimaan Teman Sebaya dengan Prestasi Akademik Mahasiswa pada Fakultas Ekonomi Universitas Negeri Jakarta", dalam JurnalEkonomi \& Pendidikan, 7, hlm.105-118. 
Taylor, Lorie K \& Sheila R. Alber. 2002. “The Comparative Effect of A Modified SelfQuestion Strategy and Story Mapping on The Reading Comprehension of Elementary Students with Learning Disabilities", dalamJournal of Behavioral Education,11, hlm.69-87.

Todd, Mary. 2016. "Going for Gold", dalam Phi Kappa Phi Forum, 96, hlm.2-2.

Trevino-Maack, Sylvia, et al. 2015. "A Group Contingency Plus Self-Management Intervention Targeting At-Risk Secondary Students' Class-Work and Active Engagement", dalam Remedial \& Special Education, 36, hlm.347-360.

Tubin, Dorit. 2015. "School Success as a Process of Structuration", dalam Educational Administration Quarterly, 51, hlm.640-674.
Veed, Glen J. 2009. The Role of the Peer Group Adolescence: Effects on Internalizing and Externalizing Symptoms. University of Nebraska: Digital Commons.

Walters, Kathryn \& Gary L. Bowen. 1997. "Peer Group Acceptance and Academic Performance Among Adolescents Participating in a Dropout Prevention Program", dalamChild and Adolescent Social Work Journal, 14, hlm.413-426.

Wentzel, Kathryn R \& Kathryn Caldwell. 1997. "Friendships, Peer Acceptance, and Group Membership: Relation to Academic Achievement in Middle School", dalamChild Development, 68, hlm. 1198-1209 